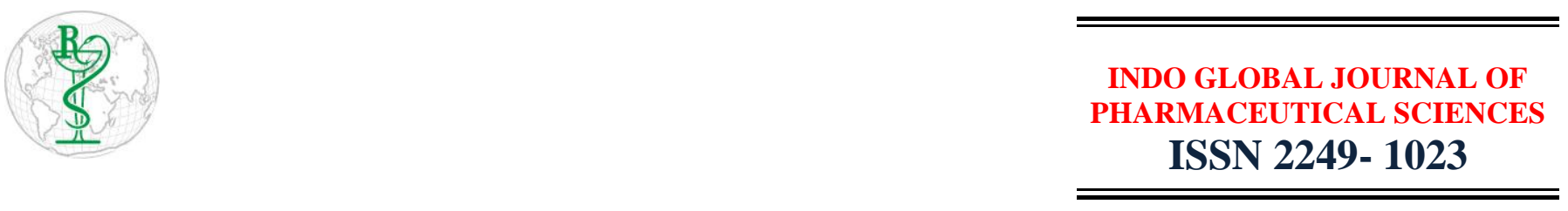

\title{
Therapeutic Management of AIDS using Ethnomedicinal Plants
}

\author{
Ramandeep Kaur *1, Pooja Sharma ${ }^{1,2}$, Dinesh Kumar ${ }^{1}$ \\ ${ }^{1}$ Sri Sai College of Pharmacy, Manawala, Amritsar-143115, Punjab, India \\ ${ }^{2}$ Department of Pharmaceutical Sciences and Drug Research, Punjabi \\ University Patiala
}

Address for Correspondence: Ramandeep Kaur; ramandeepk22990@gmail.com

Received:

01.03.2019

Accepted:

25.03.2019

Keywords

AIDS;

Antiretroviral;

Phytochemistry;

Aegle marmelos.

\begin{abstract}
Acquired Immunodeficiency Syndrome (AIDS) which is chiefly originated by a retrovirus named as Human Immunodeficiency Virus (HIV), has influenced about 70 million populations worldwide. Even though several advancements have been invented in the field of antiretroviral combination therapy, still HIV has become the dominant reason of death in South Africa. The current antiretroviral therapies have achieved success in providing instant HIV suppression but with countless undesirable adverse effects. In the present day, the biodiversity of plant kingdom is being explored by several researchers for the discovery of potent anti-HIV drugs with different mechanisms of action. The primary challenge is to afford a treatment that is free from any sort of risk of the drug resistance and serious side effects. Hence, there is a strong demand to evaluate the drugs obtained from natural plants as well as the synthetic derivatives that have been derived from the natural compounds by various chemical reactions. Several natural plants such as Andrographis paniculata, Dioscorea bulbifera, Aegle marmelos, Wistaria floribunda, Lindera chunii, Xanthoceras sorbifolia and others have displayed significant anti-HIV activity and were researched for their therapeutic principles. The synthetic derivatives of natural compounds have shown more potent anti-HIV potential with improved pharmacokinetic profile. These include the synthetic derivatives of artemisinin, andrographolide, calanolides, maslinic acid and ingenol synthetic derivatives. () 2019 iGlobal Research and Publishing Foundation. All rights reserved.
\end{abstract}

Cite this article as: Kaur, R.; Sharma, P.; Kumar, D. Therapeutic Management of AIDS using Ethnomedicinal Agents. Indo Global J. Pharm. Sci., 2019; 9(2Suppl.): $143 . \quad$ DOI: http://doi.org/10.35652/IGJPS.2019.92S41 .

Indo Global Journal of Pharmaceutical Sciences( ISSN 2249 1023; CODEN- IGJPAI; NLM ID: 101610675) indexed and abstracted in CrossRef (DOI Enabling), UGC CARE Journal List, EMBASE(Elsevier), National Library of Medicine (NLM) Catalog, ResearchGate, Publons, CAS (ACS), Index Copernicus, Google Scholar and many more. For further details, visit http://iglobaljournal.com

This is a special issue as an outcome of 'RAPSCON-2019' sponsored by APTI and organized by Sri Sai College of Pharmacy, Manawala, Amritsar, Punjab, India. Relaxation offered in journal format. 